\title{
Two Stay Two STRAy CoOperative LEARNING ON STUDENT LEARNING OUTCOMES ON MATERIALS OF GEOMETRY SURFACE AREA
}

\author{
Desilia Elisabet $^{1)}$, Agung Hartoyo $^{2)}$, Yulis Jamiah ${ }^{3)}$ \\ ${ }^{1)}$ Universitas Tanjungpura, Pontianak, Indonesia \\ E-mail: elisabetdesilia@gmail.com \\ ${ }^{2)}$ Universitas Tanjungpura, Pontianak, Indonesia \\ E-mail: agung.hartoyo@fkip.untan.ac.id \\ ${ }^{3)}$ Universitas Tanjungpura, Pontianak, Indonesia \\ E-mail: yulis_jamiah@yahoo.co.id
}

\begin{abstract}
This study aims to determine whether there is an effect of Two Stay Two Stray cooperative learning on student learning outcomes on the surface area material. The method used in this study is an experimental method with a quasi-experimental form and the research design is Posttest-Only Control Design. The population of this study were all class IX students of SMP Negeri 18 Pontianak for the 2018/2019 academic year which were spread into five classes. The samples of this research were students of class IX D and IX E who were taken by using a simple random sampling technique (simple random sampling). Data collection techniques using measurement techniques and data collection tools with test descriptions used to determine student learning outcomes. After the data was tested in the two samples, the data analysis was then carried out to test the hypothesis. Before the Hypothesis test was carried out, the prerequisite was first tested, namely the Normality Test, because the abnormal normality test, the hypothesis test used the Mann Whitney UTest. From the results of data analysis, the $z_{\text {count }}$ value was obtained equal to 1.87 while the value of $z_{\text {table }}$ of 1.64 for $\alpha=$ 0.05 . Because of the value of $z_{\text {count }}>z_{\text {table, }}$ it is concluded that there is an effect of cooperative learning Two Stay Two Stray on student learning outcomes.
\end{abstract}

Keywords: Surface Area; Geometry; Cooperative Learning; Two Stay Two Stray

\section{INTRODUCTION}

Learning is something that cannot be separated in our daily life. Likewise with education is one important aspect of human life as well as in the development of a nation. The importance of education is also stated in article 31 of the 1945 Constitution which states that every citizen has the right to have an education and the government seeks and provides education to educate the nation (Lukita, 2017).

Mathematics is a science that deals with numbers and are closely related to counting (Perwitasari \& Shaifuddin, 2014). Mathematics learning in schools should be able to involve various learning models that can help in learning activities so that students feel interested in taking lessons in class.

The reality in the field today shows that mathematics learning carried out by teachers in schools is rarely related to the reality of social life in society so that it has human values.
So that the learning that is currently taking place tends to be oriented to textbooks only so that the results are less meaningful for the social life of students. For students to gain social experiences, learning that is carried out should seek to foster interaction between all students sharing and complementing each other so that the learning knowledge obtained is the result of shared thinking (Johnson \& Johnson, 2013).

To find out the conditions in the field, researchers conducted direct observations of the learning process in the classroom carried out by the class IX mathematics teacher. These observations show that learning activities begin with the teacher's explanation of the material being studied. In explaining the material, the teacher uses the lecture method. Furthermore, the teacher also provides sample questions and exercises about the material being studied to test students' understanding. Through observation, it was seen that there were still many students who had difficulty starting the 
completion, students often waited for the teacher's instructions when they started solving questions.

In solving math problems, students are less empowered in learning mathematics. It is also indicated that teachers in teaching mathematics do not involve students' mathematical problem-solving abilities. This can be seen from the textbooks used by the teacher which do not require the ability of students to re-check the answers to questions that are part of solving mathematical problems (Lestari, 2014).

Furthermore, the researcher also conducted interviews with class IX mathematics teachers. From the results of the interview obtained information that the ability of students in determining the surface area of a room is still low. This fact is assessed from the value of daily tests, especially in the shape of the tube and cone space. Students also often experience difficulties in determining the surface area of cubes and cones, even though the learning carried out by the teacher always provides examples of various questions on the questions themselves and in terms of problem-solving.

Based on this condition, it is necessary to solve problems through the application of good learning as the key to the success of learning mathematics. In this case, teachers are required to make learning innovations by implementing student-centred learning to arouse student interest and activeness in learning activities. Learning that involves active student participation is Two Stay Two Stray cooperative learning (Nurhusain, 2017).

The role of the teacher here is as a facilitator, encouraging students to develop their potential optimally. Two Stay Two Stray cooperative learning is cooperative learning that can make students active, can increase student motivation because every student has learning responsibilities, both for himself and his group. Two Stay Two Stray cooperative learning is a way of providing opportunities to increase creativity and increase critical thinking skills.

Two Stay Two Stray cooperative learning is a model of cooperative learning that can increase student activity and create a pleasant learning atmosphere (Indriyani, 2011). According to Amar (2012), the structure Two Stay Two Stray or Structures Two Living Two Guests, namely giving groups to share results and information with other groups. In its activities, Two Two Stay Two Stray cooperative learning is carried out in groups with one group of four people.

Two students in each group are tasked with visiting other groups like guests. The purpose of visiting other groups is to get information and opinions from other groups regarding the material being studied. Both guests should note if there is important or missing information in their group regarding the material being studied. This visiting activity can be done by each group a maximum of two times.

Then some students are assigned to live in groups. The task of the remaining students is to share their group's work and information with guests from other groups about the material that has been studied. Then students just try to provide explanations according to their knowledge of the material that has been studied to their guests. Each student who stays should serve their guests well, that is, answer any questions or information that the students who visit their groups want to know.

Two Stay Two Stray learning in this study was carried out in 4 steps, namely (1) group discussion, (2) visiting and staying, (3) discussion and (4) concluding (Lie, 2010). Before the learning activities begin, the teacher delivers information and learning objectives regarding Two Stay Two Stray cooperative learning on the material of the geometry surface area.

From the learning steps that have been disclosed, it can be seen that Two Stay Two Stray cooperative learning teaches students to be creative in finding various information related to the subject matter for their group. It can also be seen that this model teaches positive qualities for students, namely cooperation, mutual giving and being willing to accept and the habit of not being ashamed to ask questions if they have difficulty learning a subject matter. Besides, students automatically begin to be accustomed to doing peer tutoring activities even though the language is still simple. Thus, students' knowledge and insights develop, students, master the topic of discussion so that student learning outcomes can be improved (Fitriyah \& Purwantoyo, 2012).

Two Stay Two Stray cooperative learning matches the characteristics of students at SMP Negeri 18 Pontianak who are used to discussing and sharing with peers so that they can apply these habits of discussion and sharing in Two Stay Two Stary cooperative learning. Besides, students are also familiar with using material text or worksheets so that they do not experience problems with the text of the material to be used in learning activities. The material studied also supports the implementation of learning activities because it is suitable to be delivered using Two Stay Two Stray cooperative learning.

Thus, the application of Two Stay Two Stray cooperative learning which will be used as a treatment in this study has a great opportunity to be able to improve student learning outcomes because it is following student learning habits and matches the material to be studied. According to Lie (2010), Two Stay Two Stray cooperative learning is suitable for elementary and junior high school students because the learning activities involve activities that students usually do in their daily lives, namely visiting and receiving guests. Two Stay Two Stray cooperative learning will make the learning atmosphere active, creative and not boring for students.

Manik and Gafur (2016) stated that Two Stay Two Stray cooperative learning has the following advantages: (1) Two Stay Two Stray cooperative learning can be applied to various classes or age levels; (2) Student learning becomes more meaningful to provide opportunities for students to form concepts independently in their way; (3) Two Stay Two Stray cooperative learning can make students active because each student has their activities and responsibilities in their group; (4) Using Two Stay Two Stray cooperative learning, teachers can increase student motivation. This is evident when they exchange information; (5) Students are actively involved in learning and all group members are required to report the results of their visits to other groups (for students who visit/stray) and the results obtained during guest visits in their groups (for students who live/stay), so it can have an 
increasing effect learning outcome and student memory; (6) Students who live in groups (stay) have the opportunity to increase creativity, for example when they present their group work to guests (other group members) who visit their group; (7) When students compare the results of their group work with the work of other groups, it means that the teacher has allowed students to improve their critical thinking skills, where they will try to look at other people's work and the work of their groups; (8) Using Two Stay Two Stray cooperative learning can help teachers provide information about ongoing learning. Learning by getting staff in the form of peer tutors when a group member exchanges information, confirms, presentations, and asks other group members.

This research is different from previous research which only visited and stayed and only got the information without a strong understanding of the subject matter. This study, apart from using Two Stay Two Stray cooperative learning, also uses teaching materials in the form of learning videos that are displayed in the classroom. The instructional videos and text materials are made to attract students' interest in learning during the learning process. With this students can learn with their sense of hearing and sense of sight simultaneously.

Learning materials that are currently developing are very helpful for teachers in the learning process. According to Arsyad (2011), through an argument in the form of a cone of experience, it is stated that $75 \%$ of a person's learning experience is obtained through the sense of sight (eyes), $13 \%$ through the sense of hearing (ears), and the rest $12 \%$ through other senses. Learning using multiple senses such as sight and hearing will benefit students.

\section{Methodology}

\section{A. Research Methods and Forms}

The method used in this research is an experimental method with a quasi-experimental form. The quasi-experimental form is used because the researcher can't control and manipulate all relevant variables as actual experimental research. In educational research, it is often difficult to control or manipulate all the relevant variables in this study (Sugiyono, 2017).

\section{B. Research design}

The design used in the study was Posttest-Only Control Design, namely a one-time test design for two groups. Measurements are made after the treatment is given. This design has two classes, namely the experimental class and the control class. The experimental class is a class that is given Two Stay Two Stray cooperative learning, while the control class is a class that is given conventional learning. The research design can be seen in Table I.

TABLE I

POSTTEST-ONLY CONTROL DESIGN

\begin{tabular}{ccc}
\hline Group & Treatment & Post Test \\
\hline Experiment Class & $\mathrm{X}$ & $\mathrm{O}$ \\
Control Class & - & $\mathrm{O}$ \\
\hline
\end{tabular}

(Sugiyono, 2017)
$\mathrm{X}=$ Two Stay Two Stray lesson
$\mathrm{O}=$ Posttest

\section{Population}

The population in this study were all class IX students of SMP Negeri 18 Pontianak in the 2018/2019 academic year which were spread into five classes.

\section{Sample}

The sample of this research is two classes of students of class IX SMP Negeri 18 Pontianak from five classes IX available. Because there are five classes of class IX students at SMP Negeri 18 Pontianak, the simple random sampling technique was used in selecting the sample. This is done because the placement of smart, medium, and poor students in each class is evenly distributed. The selection of the experimental class and the control class from the five available classes was done by drawing. From the results of the draw, 33 students of class IX D were selected as the experimental class and as many as 36 students were the control class in class IX E.

\section{E. Data Collection Technique}

This researcher uses measurement techniques. The measurement technique is used to obtain data about student learning outcomes after using Two Stay Two Stray cooperative learning.

\section{F. Data Collection Tools}

The data collection tool in this study was a learning outcome test in the form of an essay test, which consisted of 4 questions. The essay test used is in line with the opinion of Rochmiyati and Habibie (2019) which stated that through this essay test students can express answers and have varying levels of truth or error, thus reducing the possibility of students guessing an answer to the question. The essay test is used to test students when students solve problems in working on questions.

Indicators of students in solving problems on the surface area of a building are (1) the ability of students to understand the problems given, (2) the ability of students to plan problem solving, (3) the ability of students to solve problems, (4) the ability of students to re-examine solutions problems (Pradani, 2016).

After the preparation of the research, the instrument has been completed, the next step is to take the validity and reliability of the test questions. The results of the validity of the research instrument obtained $t_{\text {count }}$ of 4.12 and $t_{\text {table }}$ of 2.35. Because $t_{\text {count }}>t_{\text {table }}$, the research instrument is said to be valid. While the reliability value obtained is 0.661 which belongs to the high criteria. Because the test instrument is classified as valid and reliable so that this test instrument can be used in research.

\section{G. Data Analysis Techniques}

To calculate the learning outcomes of students who are given the Two Stay Two Stray type of cooperative learning and conventional learning about the surface area material of a 
room, the test score data will be calculated which is then converted into values.

Furthermore, the value will be adjusted to the minimum completeness criteria (KKM) in the mathematics field at SMP Negeri 18 Pontianak, to determine student completeness. If the value is $\geq 7.0$, the student is declared complete, but if the student's score is $<7.0$ then the student is said to be incomplete.

The data that has been obtained is then tested for normality, if the data is not normally distributed, then hypothesis testing uses non-parametric statistics. The test used is the Mann Witney U-test. Then the $z_{\text {count }}$ value is obtained with the condition, if $z_{\text {count }}>z_{\text {table }}$ then $\mathrm{Ha}$ is accepted. But when $z_{\text {count }}<$ $z_{\text {table }}$ then $\mathrm{Ha}$ is rejected.

Ho: There is no effect of Two Stay Two Stray (TSTS) cooperative learning on student learning outcomes.

Ha: There is an effect of Two Stay Two Stray (TSTS) cooperative learning on student learning outcomes

\section{RESULTS AND DISCUSSION}

\section{A. Results}

After the implementation of data collection, the results of the students' work in completing the test questions were obtained in the form of scores. After obtaining the scores and test results, then the data processing was carried out on the test scores using descriptive statistics.

For the experimental class that was given Two Stay Two Stray cooperative learning, it was obtained an average score of 34.09. The results of the conversion of scores into values on a scale of 0-10 obtained an average value of 8.52. Judging from the completeness of individual learning outcomes, in the experimental class, there were 28 students or $84.85 \%$ of the 33 students who had completed $(>7)$. Because there were more than $80 \%$ who completed individually, it means that the experimental class experienced classical completeness.

The results of data processing, the control class test scores showed an average score of 27.56. The results of the conversion of scores into values on a scale of $0-10$ obtained an average control class of 6.89. Judging from the completeness of individual learning outcomes, in the control class, there were 13 students or $36.11 \%$ of the 36 students who had completed ( $>7$ ). Because there were less than $80 \%$ of students who completed individually, it means that the control class did not experience classical completeness.

Based on the normality test, it is known that the data are not normally distributed. Then the nonparametric statistical test is carried out, namely the Mann Whitney U-Test. After the calculation is done, the $z_{\text {count }}$ value is obtained equal to 1.87 while the value of $z_{\text {table }}$ of 1.64 for $\alpha=0.05$. Because of the value of $z_{\text {count }}>z_{\text {table, }}$, it can be concluded that there is an effect of cooperative learning Two Stay Two Stray on student learning outcomes.

\section{B. Discussion}

Based on the results of data processing, the average score of the experimental class test results given the Two Stay Two Stray cooperative learning obtained an average score of 34.09.
The results of the conversion of scores into values on a scale of $0-10$ obtained an average value of 8.52. Judging from the completeness of individual learning outcomes, in the experimental class, there were 28 students or $84.85 \%$ of 33 students who had completed (>7). Because there were more than $80 \%$ who completed individually, it means that the experimental class experienced classical completeness.

The completeness of classical learning outcomes in experimental class students shows that the Two Stay Two Stray type of cooperative learning is suitable to be applied to the material on the surface area of cubes and cones.

According to Wardhani (2010), reality shows that one of the difficulties that many students experience in learning mathematics is solving problems. The difficulty is not only in linguistic problems related to the interpretation of a sentence but also difficulties in mathematical models that have a meaning related to a problem. The ability to solve mathematical problems can be seen as one of the learning processes and outcomes. If a student has practised solving problems, then in real life, that student will be able to make decisions about a problem, because he has the skills to collect relevant information, analyze information, and realize how important it is to re-examine the results that have been obtained.

The findings in the field inform that the activities of visiting and staying in the cooperative learning Two Stay Two Stary which were applied in this study turned out to make the experimental class experience classical completeness. This agrees with Lie (2010) who stated that the Two Stay Two Stary cooperative learning is suitable for elementary and junior high school students because learning activities involve activities that students usually do in their daily lives, namely visiting and receiving guests.

There can be some advantages when implementing Two Stay Two Stray type of cooperative learning activities, including (1) Two Stay Two Stray type cooperative turns out to be able to make students more enthusiastic and motivated to do learning activities. (2) Students look happy when learning because There are activities such as visiting and staying, which are social activities that they usually do in their daily life.

\section{CONCLUSIONS}

Based on the results of data processing and discussion, it can be concluded that: (1) For the experimental class that was given Two Stay Two Stray cooperative learning, it was obtained an average score of 34.09. The results of the conversion of scores into values on a scale of $0-10$ obtained an average value of 8.52. Judging from the completeness of individual learning outcomes, in the experimental class, there were 28 students or $84.85 \%$ of the 33 students who had completed (>7). Because there were more than $80 \%$ who completed individually, it means that the experimental class experienced classical completeness; (2) The results of data processing, the control class test scores show an average score of 27.56. The results of the conversion of scores into values on a scale of $0-10$ obtained an average control class of 6.89 . Judging from the completeness of individual learning 
outcomes, in the control class, there were 13 students or $36.11 \%$ Pradani, Shimawaty. (2016). Analisis Pemecahan Masalah of the 36 students who had completed $(>7)$. Because there were less than $80 \%$ of students who completed individually, it means that the control class did not experience classical completeness; (3) After the calculation is done then the $z_{\text {count }}$ value is obtained equal to 1.87 while the value of $z_{\text {table }}$ of 1.64 for $\alpha=0.05$. Because of the value of $z_{\text {count }}>z_{\text {table }}$, it can be concluded that there is an effect of cooperative learning $T w o$ Stay Two Stray on student learning outcomes on the surface area material.

Some suggestions that can be conveyed based on the results of this study include: (1) the teacher should be more observant with the division of group members so that members in each group can carry out their role as visiting students and students who live optimally, (2) teachers should get used to students dare to convey information to others, so that each student who is in charge of providing information to the visiting group can carry out his role optimally.

\section{REFERENCES}

Amar, T. (2012). Eksperimen Model Pembelajaran Kooperatif Tipe Two Stay Two stray Berbasi Open-Ended Problem kelas VII MTs N Kelirung. Jurnal Universitas Semarang (UNNES).

Arsyad, A. (2011). Media Pembelajaran. Jakarta: Rajawali Press.

Fitriyah, Nur I. \& Purwantoyo, Eling. (2012). Efektivitas Kooperatif Two Stay Two Stray Terhadap Aktivitas dan hasil Belajar Siswa. Journal UNNES.

Indriyani, C. (2011). Peningkatan kualitas pembelajaran IPS dengan model pembelajaran kooperatif teknik Two Stay Two Stray pada siswa kelas IV SD Tambakaji 05 kecamatan Ngaliyan. Jurnal Kependidikan Dasar.

Johnson, David W \& Johnson Roger T. (2013). Cooperation in the Classroom. $9^{\text {th }}$ end. Edina, MN: Interaction Company.

Lestari, Anisa. (2014). Penyelesaian Matematis Siswa. Bandung: Usaha Nasional.

Lie, Anita. (2010). Mempraktikkan Cooperative Learning di Ruang-ruang Kelas. Jakarta: PT. Grasindo Widia Sarana Indonesia.

Lukita, Nindya. (2017). Efektivitas Pembelajaran Kooperatif Two Stay Two Stray Ditinjau dari Pemahaman Konsep Matematis Siswa. Jurnal FKIP Bandar Lampung.

Manik, Kardi \& Gafur, Abdul. (2016). Penerapan Model Two Stay Two Stray Berbantuan Multimedia untuk Meningkatkan Aktivitas dan hasil belajar IPS. Journal UNY.

Nurhusain, Muhammad. (2017). Impact Analysis of Cooperative Learning Model Application Type Two Stay Two Stray (TSTS) Toward Learning Outcomes of Mathematics. Journal STKIP YPUP.

Perwitasari, S., SM, E., \& Shaifuddin, M. (2014). Penerapan Model Kooperatif Tipe The Power Of Two Untuk Meningkatkan Kemampuan Menghitung Pecahan. Jurnal Teknologi Pendidikan dan Pembelajaran. 